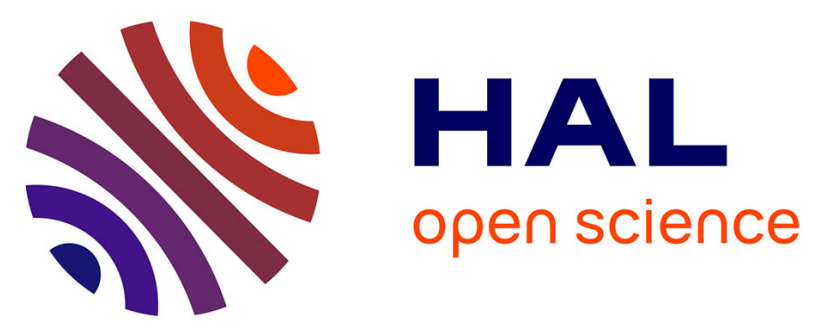

\title{
Pharmacology of EAPB0203, a novel imidazo[1,2-a]quinoxaline derivative with anti-tumoral activity on melanoma
}

Jean-François Cooper, Sonia Khier, Carine Deleuze-Masquéfa, Georges Moarbess, Florence Gattacceca, Delphine Margout, Isabelle Solassol, Frédéric Pinguet, Pierre-Antoine Bonnet, Françoise M. M. Bressolle

\section{To cite this version:}

Jean-François Cooper, Sonia Khier, Carine Deleuze-Masquéfa, Georges Moarbess, Florence Gattacceca, et al.. Pharmacology of EAPB0203, a novel imidazo[1,2-a]quinoxaline derivative with antitumoral activity on melanoma. European Journal of Pharmaceutical Sciences, 2010, 39 (1-3), pp.23-29. 10.1016/j.ejps.2009.10.006 . hal-02309653

\section{HAL Id: hal-02309653 https://hal.science/hal-02309653}

Submitted on 9 Oct 2019

HAL is a multi-disciplinary open access archive for the deposit and dissemination of scientific research documents, whether they are published or not. The documents may come from teaching and research institutions in France or abroad, or from public or private research centers.
L'archive ouverte pluridisciplinaire HAL, est destinée au dépôt et à la diffusion de documents scientifiques de niveau recherche, publiés ou non, émanant des établissements d'enseignement et de recherche français ou étrangers, des laboratoires publics ou privés. 


\section{Pharmacology of EAPB0203, a novel imidazo[1,2-a]quinoxaline derivative with anti-tumoral activity on melanoma}

Sonia Khier, Carine Deleuze-Masquéfa, Georges Moarbess, Florence Gattacceca, Isabelle Solassol, Jean-Franç Ois Cooper, Frédéric Pinguet, Pierre-Antoine Bonnet, Franç Oise, M Bressolle, et al.

\section{To cite this version:}

Sonia Khier, Carine Deleuze-Masquéfa, Georges Moarbess, Florence Gattacceca, Isabelle Solassol, et al.. Pharmacology of EAPB0203, a novel imidazo[1,2-a]quinoxaline derivative with anti-tumoral activity on melanoma. European Journal of Pharmaceutical Sciences, Elsevier, 2010, 39 (1-3), pp.2329. 10.1016/j.ejps.2009.10.006 . hal-02309653

\section{HAL Id: hal-02309653 \\ https://hal.archives-ouvertes.fr/hal-02309653}

Submitted on 9 Oct 2019

HAL is a multi-disciplinary open access archive for the deposit and dissemination of scientific research documents, whether they are published or not. The documents may come from teaching and research institutions in France or abroad, or from public or private research centers.
L'archive ouverte pluridisciplinaire HAL, est destinée au dépôt et à la diffusion de documents scientifiques de niveau recherche, publiés ou non, émanant des établissements d'enseignement et de recherche français ou étrangers, des laboratoires publics ou privés. 


\title{
Pharmacology of EAPB0203, a novel imidazo[1,2-a]quinoxaline derivative with anti-tumoral activity on melanoma
}

\author{
Sonia Khier a , Carine Deleuze-Masquéfa ${ }^{\mathrm{b}, 1}$, Georges Moarbess ${ }^{\mathrm{b}, 1}$, Florence Gattacceca ${ }^{\mathrm{a}}$, \\ Delphine Margout ${ }^{\mathrm{a}}$, Isabelle Solassol ${ }^{\mathrm{c}}$, Jean-François Cooper ${ }^{\mathrm{d}}$, Frédéric Pinguet ${ }^{\mathrm{c}}$, \\ Pierre-Antoine Bonnet ${ }^{\mathrm{b}}$, Françoise M.M. Bressolle ${ }^{\mathrm{a}, *}$ \\ ${ }^{a}$ Clinical Pharmacokinetic Laboratory, EA4215, Faculty of Pharmacy, 15 Avenue Ch. Flahault, University Montpellier I, B.P. 14491, 34093 Montpellier Cedex 5, France \\ ${ }^{\mathrm{b}}$ Pharmacochemistry and Biomolecule Laboratory, EA4215, Faculty of Pharmacy, 15 Avenue Ch. Flahault, University Montpellier I, 34093 Montpellier Cedex 5, France \\ c Oncopharmacology Department, Pharmacy Service, Val d'Aurelle Anticancer Centre, Parc Euromédecine, 34298 Montpellier Cedex 5, France \\ d Biochemistry and Environment Laboratory, EA4215, Perpignan University, 66860 Perpignan Cedex 9, France
}

\section{A R T I C L E I N F O}

\section{Article history:}

Received 27 July 2009

Received in revised form

30 September 2009

Accepted 13 October 2009

Available online $\mathrm{xxx}$

\section{Keywords:}

Imidazo[1,2-a]quinoxaline

LC/ESI-MS

Melanoma

In vitro and in vivo cytotoxic activities

Pharmacokinetics

Sub-acute toxicity

\begin{abstract}
A B S T R A C T
In spite of the development of new anticancer drugs by the pharmaceutical industry, melanoma and $\mathrm{T}$ lymphomas are diseases for which medical advances remain limited. Thus, there was an urgent need of new therapeutics with an original mechanism of action. Since several years, our group develops quinoxalinic compounds. In this paper, the first preclinical results concerning one lead compound, EAPB0203, are presented. This compound exhibits in vitro cytotoxic activity on A375 and M4Be human melanoma cell lines superior to that of imiquimod and fotemustine. A liquid chromatography-mass spectrometry method was first validated to simultaneously quantify EAPB0203 and its metabolite, EAPB0202, in rat plasma. Thereafter, the pharmacokinetic profiles of EAPB0203 were studied in rat after intravenous and intraperitoneal administrations. After intraperitoneal administration the absolute bioavailability remains limited (22.7\%). In xenografted mouse, after intraperitoneal administration of 5 and $20 \mathrm{mg} / \mathrm{kg}$, EAPB0203 is more potent than fotemustine. The survival time was increased up to 4 and 2 weeks compared to control mice and mice treated by fotemustine, respectively. The results of this study demonstrate the relationship between the dose of EAPB0203 and its effects on tumor growth. Thus, promising efficacy, tolerance and pharmacokinetic data of EAPB0203 encourage the development towards patient benefit.
\end{abstract}

\section{Introduction}

Melanoma is an increasingly common, potentially fatal form of skin cancer arising from the malignant transformation of melanocytes. Responsible of several thousand deaths each year, melanoma is the most frequent malignant tumor in the white human population worldwide (Greinert, 2009). Its frequency increases dramatically with age and chronic sun exposure. Only a few chemotherapeutic agents that are active in fighting cancer cells have been shown to be active in the treatment of melanomas, either one at a time or in combinations. Imidazoquinoline compounds have potent antiviral and antitumor properties in animals, and have been clinically approved for the topical treatment of genital and anal warts (Hengge and Cusini, 2003; Sauder, 2003). Imiquimod, the first member of the imidazoquinolone family is

\footnotetext{
* Corresponding author. Tel.: +33 4675480 75; fax: +33 467548075 .

E-mail address: FBressolle@aol.com (F.M.M. Bressolle).

${ }^{1}$ Both these authors contributed equally to this work.
}

efficacious as a topical therapy for certain types of skin cancers: basal cell carcinoma, Bowen's disease, superficial squamous cell carcinoma, some superficial malignant melanomas and actinic keratosis (Steinmann et al., 2000; van Egmond et al., 2007). Extensive studies over the past years have indicated that imiquimod acts both: (i) indirectly, by activating the innate as well as the adaptive immune system via binding to cell surface receptors such as Toll-like receptors (TLR) 7 and 8, thereby inducing the activation of transcription factors like nuclear factor NF- $\kappa B$ and resulting in the secretion of pro-inflammatory cytokines predominantly interferon (IFN)- $\alpha$, tumor necrosis factor (TNF)- $\alpha$ and interleukin(IL)-12 (Hemmi et al., 2002; Hengge and Cusini, 2003; Rudy, 2002; Sauder, 2003); and (ii) directly, by inducing direct in vitro and in vivo pro-apoptotic activities in a rather tumor selective manner, requiring the activation of the 'work horses' of apoptosis, the caspases' family of proteases (Schön et al., 2003, 2004). Imiquimod inhibits melanogenesis and proliferation of human melanocytes (Kang et al., 2009). Recently, its therapeutic spectrum was extended to cutaneous B-cell lymphomas (Spaner et al., 2005). Resiquimod, analog of imiquimod, has greater potency at inducing cytokine 
expression. Unfortunately, imiquimod and particularly resiquimod cannot be administered intravenously due to their toxicities. The interesting double mechanism of action of these compounds prompts us to synthesize analogs of imiquimod. Based on this knowledge, a new series of compounds has been synthesized, the imidazo[1,2-a]quinoxalines, in order to evaluate its potential anticancer properties, particularly in the treatment of melanoma and T lymphomas (Deleuze-Masquéfa et al., 2009a; Moarbess et al., 2008a). Among the synthesized compounds, two of them, EAPB0203 and EAPB0503, have the highest in vitro cytotoxic activity on melanoma (Deleuze-Masquéfa et al., 2009a; Moarbess et al., 2008a). Moreover, EAPB0203 at the dose of $20 \mathrm{mg} / \mathrm{kg}$ by intraperitoneal route was more potent than fotemustine in xenografted nude mice (Moarbess et al., 2008a). EAPB0203 also had promising cytotoxic activity on T lymphomas (Moarbess et al., 2008b). Recently a liquid chromatography-mass spectrometry (LC-MS) method has been developed to quantify EAPB0503 and its main metabolite in human and rat plasma (Khier et al., 2009). It was used to carry out a pharmacokinetic study in rat after administration of this compound intravenously.

The aim of the present paper was: (i) to develop a LC-MS method to quantify EAPB0203 and its main metabolite, EAPB0202, in rat plasma; (ii) to determine pharmacokinetic parameters of these two compounds in rat after intravenous and intraperitoneal administrations; (iii) to estimate the sub-acute toxicity of ЕАPB0203 in rat after repeated intravenous administrations, once a day for 5 consecutive days; and (iv) to evaluate the in vivo activity of EAPB0203 in xenografted nude mice at a lower dose $(5 \mathrm{mg} / \mathrm{kg})$ in order to establish dose-response curve.

\section{Materials and methods}

\subsection{Chemistry}

EAPB0203 ( $N$-methyl-1-(2-phenethyl)imidazo[1,2-a]quinoxalin-4-amine; molecular weight, 302; $\log P, 4.91 ; \mathrm{p} K_{\mathrm{a}}$, 5.61), EAPB0202 (1-(2-phenethyl)imidazo[1,2-a]quinoxalin4-amine; molecular weight, 288; $\left.\log P, 4.97 ; \mathrm{p} K_{\mathrm{a}}, 5.13\right)$ and the internal standard (IS, EAPB0603, 1-(3-hydroxyphenyl)- $N$ methylimidazo[1,2-a]quinoxalin-4-amine; molecular weight, 290) used for method validation were synthesized according to a previously reported method from our group (Moarbess et al., 2008a; Deleuze-Masquéfa et al., 2009a, patent no. FR 2921927; patent $\mathrm{N}^{\circ}$ WO 2009043934). Briefly, they were synthesized in good yields via a bimolecular condensation of 2-imidazole carboxylic acid, followed by a coupling with ortho-fluoroaniline and subsequent substitution on the imidazole ring by Suzuki Cross-Coupling reaction using microwave assistance. The purity of these standards was evaluated by elemental analysis, liquid chromatography-mass spectrometry (LC-MS) and NMR. They were stored at $20^{\circ} \mathrm{C}$ protected from light.

\subsection{Chemicals and reagents}

All reagents were of analytical grade. Purified water (MilliQ purification system, Millipore, Bedford, MA, USA), trifluoroacetic acid (TFA, Sigma, St. Louis, MO, USA), acetonitrile and dichloromethane (Carlo Erba, Val de Reuil, France), ammonium formate (Fluka, Vandoeuvre, France), formic acid (Prolabo, Paris, France) and Oasis HLB cartridges (30 mg sorbent, Waters, Saint Quentin, France) were used. Drug-free rat plasma provided from Charles River (L'Arbresle Cedex, France). Ammonium formate buffer was prepared by mixing ammonium formate and water to a concentration of $2 \mathrm{mM}$; the $\mathrm{pH}$ was adjusted to $\mathrm{pH} 3$ with formic acid. Stock solutions of EAPB0203, EAPB0202 and IS (40 mg/L) were prepared in a mixture of acetonitrile-water-formic acid (49.5:49.5:1, v/v/v). These solutions were further diluted extemporaneously with the same mixture as appropriate to prepare working solutions (EAPB0203 and EAPB0202: $0.125-25 \mathrm{mg} / \mathrm{L}$; IS: 1.6 and $8 \mathrm{mg} / \mathrm{L}$ ). These stock solutions were stored at $+4{ }^{\circ} \mathrm{C}$ for 1 month.

\subsection{LC-MS analysis}

LC separation and MS detection were performed using a Hewlett Packard Agilent 1100 quadrupole mass spectrometer working with an electrospray ionization source (ESI) (Agilent Technologies, Les Ulis, France). The LC-MS conditions were close to those previously published for two other compounds of the same chemical series (Khier et al., 2009). The chromatographic separation was achieved on a C8 Zorbax eclipse XDB analytical column $(150 \mathrm{~mm} \times 4.6 \mathrm{~mm}$, $5 \mu \mathrm{m}$, Agilent Technologies). The optimum mobile phase consisted of, acetonitrile as solvent $A$ and $2 \mathrm{mM}$ ammonium formate as buffer $B$. The gradient elution was employed according to the following linear programme: time zero, $30 \%$ solvent $A ; 9$ min, $100 \%$ solvent $A ; 10$ min, $100 \%$ solvent $A ; 11$ min, $30 \%$ solvent $A$; and $14 \mathrm{~min}, 30 \%$ solvent $A$. The flow rate was $0.8 \mathrm{~mL} / \mathrm{min}$ and the injection volume was $10 \mu \mathrm{L}$; the column was maintained at $20^{\circ} \mathrm{C}$ and the autosampler temperature was $4{ }^{\circ} \mathrm{C}$. The data acquisition was under the control of HPChem Software (version 08.04, Agilent Technologies). The mass spectrometer was operated in positive ion mode. Heated $\mathrm{N}_{2}$ gas $\left(350^{\circ} \mathrm{C}\right.$ and $\left.10 \mathrm{~L} / \mathrm{min}\right)$ was used to evaporate solvent from the electrospray chamber and compressed $\mathrm{N}_{2}$ gas (35 psi) was used for nebulisation. Voltages were set at $+3.0 \mathrm{kV}$ for the capillary and $+0.5 \mathrm{kV}$ for the skimmer lens. The sampling cone voltages were set at $100 \mathrm{~V}$ for EAPB0203 and IS, and at $80 \mathrm{~V}$ for EAPB0202. For quantitative measurement of EAPB0203 and EAPB0202, selective ion monitoring (SIM) was employed.

\subsection{Quantitation of EAPB0203 and EAPB0202 in rat plasma}

\subsubsection{Sample preparation}

A sample pre-treatment procedure close to that previously described to analyse other compounds of the same chemical series, in rat and human plasma (Khier et al., 2009), was used with success to quantify these two new compounds. Briefly, rat plasma samples were pretreated to remove proteins. For this reason, $0.5 \mathrm{~mL}$ of water containing $10 \mathrm{~mL} / \mathrm{L}$ TFA was added to $0.5 \mathrm{~mL}$ of plasma samples (calibrators, QC or unknown samples) containing the internal standard solution $(20 \mu \mathrm{L}, 1.6 \mathrm{mg} / \mathrm{L}$ for low calibration curves, $8 \mathrm{mg} / \mathrm{L}$ for high calibration curves). After centrifugation $\left(4^{\circ} \mathrm{C}\right)$ for $10 \mathrm{~min}$ at $4000 \times \mathrm{g}$, the supernatant was transferred onto an Oasis HLB cartridge preconditioned with $1 \mathrm{~mL}$ of methanol and $1 \mathrm{~mL}$ of water. The cartridge was then washed with $1 \mathrm{~mL}$ of water and the analytes were eluted with $2 \mathrm{~mL}$ of dichloromethane. The eluates were evaporated to dryness under nitrogen at $40^{\circ} \mathrm{C}$. The residue was reconstituted with $100 \mu \mathrm{L}$ of a mixture containing acetonitrile-water-formic acid (49.5:49.5:1, $\mathrm{v} / \mathrm{v} / \mathrm{v})$.

\subsubsection{Calibration curves and QC samples}

To $0.5 \mathrm{~mL}$ of blank rat plasma, $20 \mu \mathrm{L}$ of working solutions of the two analytes were added in order to obtain calibration curves in the $5-300 \mu \mathrm{g} / \mathrm{L}$ (low calibration curves), and 100-1000 $\mu \mathrm{g} / \mathrm{L}$ (high calibration curves) ranges.

Six levels of QC samples $(15,75,200,300,500$ and $750 \mu \mathrm{g} / \mathrm{L})$ were prepared by adding to $0.5 \mathrm{~mL}$ of drug-free matrix $20 \mu \mathrm{L}$ of the QC working solutions. 


\subsubsection{Method validation}

To link peak area ratios and theoretical concentrations of each analyte, two models were tested: (i) least-squares linear regression analysis and (ii) quadratic relationship. The resulting equation parameters were used to calculate "back-calculated" concentrations for the calibrators, which were then statistically evaluated (Bressolle et al., 1996). Between-day accuracy and precision of the method were studied by analyzing QC samples (7-14 replicates per QC) against a calibration curve and were expressed as percentage recovery and relative standard deviation (R.S.D.) of replicate measurements, respectively. In order to test whether it was possible to apply the described method to samples whose rat plasma concentrations were higher than the last calibration point, a QC sample containing $1600 \mu \mathrm{g} / \mathrm{L}$ of EAPB0203 and $1920 \mu \mathrm{g} / \mathrm{L}$ of EAPBO202 was prepared, diluted 5-fold with blank drug-free rat plasma and analyzed 6 times against a calibration curve. The absolute extraction efficiencies for EAPB0203 and EAPB0202 were determined based on the comparison of the peak areas of extracted QC samples with those obtained by direct injections of the same amount of both compounds ( $n=3$ per concentration) dissolved in acetonitrile-water-formic acid (49.5:49.5:1, v/v/v). The extraction recovery of the internal standard was also calculated. The lower limit of quantitation (LLOQ) was defined as the lowest drug concentration that could be determined with a precision $\leq 20 \%$ and a recovery of $80-120 \%$.

The matrix effect was studied at the concentrations of QC samples (prepared in six different pools of rat plasma in triplicate) and was measured by referring the post-extracted spiked sample to the unextracted samples (Viswanathan et al., 2007). To evaluate assay specificity drug-free plasma samples from six different pools were extracted without IS and analyzed for endogenous co-eluting interferences.

\subsubsection{Stability assays}

For the stability study in rat plasma, drug-free control plasma samples were spiked with EAPB0203 and EAPB0202 at the concentrations of QC samples and analyzed against a calibration curve: (i) immediately, (ii) after storage at 20 and $4{ }^{\circ} \mathrm{C}$ for $4 \mathrm{~h}$, (iii) after storage at $-80^{\circ} \mathrm{C}$ for 1 month, and (iv) after three freeze-thaw cycles. Each determination was performed in triplicate. The potential influence of the evaporating step was also tested. Run-time stability at $4{ }^{\circ} \mathrm{C}$ for $48 \mathrm{~h}$ of processed samples in the autosampler was determined for each calibrator.

\subsection{In vitro cytotoxic activity study}

Experiments were conducted with two human melanoma cancer cell lines: A375 and M4Be. These cell lines were obtained from American Type Culture Collection (Rockville, MD, USA). Cells were maintained in RPMI-1640 (A375) or DMEM (M4Be) medium (Gibco Laboratories, France) supplemented with $10 \%$ heat-inactivated $\left(56^{\circ} \mathrm{C}\right.$ ) foetal bovine serum (FBS) (Polylabo, Paris, France), $2 \mathrm{mM}$ L-glutamine, $100 \mathrm{IU} / \mathrm{mL}$ penicillin G sodium, $100 \mu \mathrm{g} / \mathrm{mL}$ streptomycin sulphate, and $0.25 \mu \mathrm{g} / \mathrm{mL}$ amphotericin B. Cells were cultured at $37{ }^{\circ} \mathrm{C}$ under $95 \%$ relative humidity in an atmosphere containing $5 \%$ carbon dioxide in air. Only exponentially growing viable cells were used for the study. The doubling times of A375 and M4Be, in our experimental conditions, were approximately $18-20 \mathrm{~h}$. The day of experiment, cells were harvested with $0.02 \%$ trypsin, $0.05 \%$ EDTA (Gibco Laboratories, France) for $5 \mathrm{~min}$ at $37^{\circ} \mathrm{C}$, counted and resuspended. Then, $200 \mu \mathrm{L}$ of cell suspension (i.e., 5000 cells/well) were seeded with a multichannel pipette into the individual wells of a 96-well tissue culture plate with lid (TPP, Trasadingen, Switzerland), and allowed to attach overnight. After $20-24 \mathrm{~h}$ incubation, the medium was aspirated carefully from the plates using a sterile Pasteur pipette, and cells were exposed (in triplicate) (i) to vehicle controls ( $1 \%$ DMSO/culture medium (v/v) and culture medium alone), (ii) fotemustine and imiquimod at concentrations of $10^{-4}$ to $10^{-10} \mathrm{M}$, diluted in the culture medium, and (iii) EAPB0203 and EAPB0202 $\left(10^{-4}\right.$ to $\left.10^{-10} \mathrm{M}\right)$ dissolved in a mixture $1 \% \mathrm{DMSO} /$ culture medium (v/v). After $96 \mathrm{~h}$ of incubation, the supernatant of each well was aspirated and $10 \mu \mathrm{L}$ of MTT solution ( $5 \mathrm{mg} / \mathrm{mL}$ in phosphate-buffer saline $\mathrm{pH} 7.3$ ) was added to each well. The plates were incubated for $4 \mathrm{~h}$ at $37^{\circ} \mathrm{C}$. Thereafter, the supernatant was carefully aspirated, and $100 \mu \mathrm{L}$ of a mixture of isopropyl alcohol and $1 \mathrm{M}$ hydrochloric acid (96/4, v/v) was added to each well. After $10 \mathrm{~min}$ shaking, the optical density was measured at $570 \mathrm{~nm}$ in a microculture plate reader (Dynatech MR 5000, France). Each experiment was performed 3 times. Cell survival was expressed as percent of vehicle control. The $\mathrm{IC}_{50}$ values defined as the concentrations of drugs which produced $50 \%$ cell growth inhibition, $50 \%$ reduction of absorbance, were estimated from the sigmoidal dose-response curves.

\subsection{In vivo studies}

This research adhered to the "Principles of Laboratory Animal Care" (NIH publication \#85-23, revised 1985). The animal studies were approved by the local Animal Use Committee.

\subsubsection{Pharmacokinetics}

Sprague-Dawley rat were randomly distributed in two experiment groups. In the first group, rats received EAPB0203 intravenously at the dose of $2.5 \mathrm{mg} / \mathrm{kg}$ into the penis vein; in the second group, rats received EAPB0203 by intraperitoneal route at the dose of $2.5 \mathrm{mg} / \mathrm{kg}$. Doses were chosen according to the $50 \%$ lethal dose after intravenous administration $(14.7 \mathrm{mg} / \mathrm{kg})$. Blood samples (one sample per rat) were obtained at the following times (3 animals per time-point): 5, 10, $30 \mathrm{~min}$, and 1, 2, 4, 8, 12, 24 and $36 \mathrm{~h}$ after drug administration. Blood samples were collected in heparinized polypropylene tubes $(0.1 \mathrm{~mL}$ lithium heparinate per tube) after sacrifice of the animal by section of the carotid artery, then immediately placed on ice. Two minutes prior to sampling, animals were anaesthetized with sevofluran. Blood samples were centrifuged $(4000 \times \mathrm{g})$ at $4{ }^{\circ} \mathrm{C}$ for $10 \mathrm{~min}$. The plasma was separated then immediately stored at $-80^{\circ} \mathrm{C}$ until assay. Pharmacokinetic parameters (CL (total clearance); Vd (steady-state volume of distribution); AUC (area under curve) and terminal half-life) were calculated by non-compartmental analysis from the average concentration values at each time point using the Pk-fit software (Farenc et al., 2000; RDPP, 1999). When the concentrations were below the quantification level, the mean values were obtained from several values at, or above, the LLOQ with the other values taken as zero.

\subsubsection{Sub-acute toxicity in rat}

Rats were randomly distributed in three experiment groups: (i) in the first group, 5 rats received intravenous administrations of EAPB0203 $(5 \mathrm{mg} / \mathrm{kg}$ dissolved in $100 \mu \mathrm{L}$ DMSO) into the tail vein, once a day for 5 consecutive days; (ii) in the second group, 3 rats received the vehicle ( $100 \mu \mathrm{L}$ DMSO) once a day for 5 consecutive days; and in the third group, 3 rats were untreated (control group). All rats were examined at least twice a day so as to record any signs of ill-health or behavior changes. The bodyweight was controlled daily as well as the quantity of food and tap water consumed. To evaluate possible bone narrow toxicity, blood samples $(0.5 \mathrm{~mL}$, collected in EDTA polypropylene tubes) were drawn by cardiac puncture just prior to drug administration, then 4 and 7 days after the beginning of treatment. The following hematological parameters, platelet count, red blood cells count, white blood cells 
count, hemoglobin and hematocrit, were determined. After 5 days of treatment, animals were euthanized, and a gross necropsy was performed. Brain, heart, liver, lung, kidney, and intestine were fixed in $10 \%$ buffered formalin, embedded in paraffin-wax, sectioned, stained with hematoxylin-eosin then evaluated microscopically.

\subsubsection{Cytotoxic activity in xenografted mouse}

We have previously shown that EAPB0203 $(20 \mathrm{mg} / \mathrm{kg}$ i.p., twice a week (monday and thursday) for 3 weeks followed by a second cycle after a wash-out of 15 days), had significant higher anti-tumor activity in human melanoma (M4Be) xenografted nude mice than fotemustine (weekly i.p. administration of $20 \mathrm{mg} / \mathrm{kg}$ for 3 weeks followed by a second cycle after a wash-out of 15 days) (Moarbess et al., 2008a). In this paper, the in vivo cytotoxic activity of EAPB0203 was studied at a lowest dose and dose-response curves are presented. Tumor cells $\left(3 \times 10^{6}\right)$ were inoculated subcutaneously into the flank area of female Swiss Nude mice as previously described (Moarbess et al., 2008a). Tumor growth was monitored twice a week. At a tumor size of $\sim 0.7 \mathrm{~cm}^{3}$ (i.e., 2 weeks after the graft), athymic mice were randomly distributed into three experiment groups (6 mice per group): (i) the vehicle control group (weekly i.p. administration of DMSO/intralipid (50:50, v/v) for 3 weeks), (ii) the EAPB0203 group (weekly i.p. administration of $5 \mathrm{mg} / \mathrm{kg}$ for 3 weeks), and (iii) the fotemustine group (weekly i.p. administration of $5 \mathrm{mg} / \mathrm{kg}$ for 3 weeks). Only one cycle of treatment was performed. EAPB0203 being poorly soluble in water, it was dissolved in a mixture intralipid/DMSO (50:50, v/v). Fotemustine was dissolved in $0.9 \%$ glucose. Animals were euthanized with $\mathrm{CO}_{2}$ when the tumor size reached $2 \mathrm{~cm}^{3}$. A one-way ANOVA for repeated measurements was performed to compare (i) the variations in tumor volume between the three treatment groups (control, fotemustine and EAPB0203), a simple contrast test was used to compare 2-by-2 each group; and (ii) the efficacy of EAPB0203 treatment according to the administered doses ( 5 and $20 \mathrm{mg} / \mathrm{kg}$ ). This analysis was performed using the PK-fit software (Farenc et al., 2000; RDPP, 1999). Probability values of less than 0.05 were considered statistically significant.

\section{Results}

\subsection{Quantitation of EAPB0203 and EAPB0202 in rat plasma}

\subsubsection{Mass spectra and chromatography}

EAPBO203 and EAPB0202 were evidenced by the protonated molecules, $[\mathrm{M}+\mathrm{H}]^{+}$, at $m / z 303$ and 289 , respectively. The internal standard was characterized by the protonated molecule $[\mathrm{M}+\mathrm{H}]^{+}$ at $m / z 291$. Representative chromatograms of a prespiked $(5 \mu \mathrm{g} / \mathrm{L})$ plasma extracted sample are presented in Fig. 1. The retention times of EAPB0203, EAPB0202 and internal standard were 8.2, 7.3 and $5.6 \mathrm{~min}$, respectively. Based on the distribution of the residuals (i.e., difference between nominal and back-calculated concentrations), on the mean relative predictor error calculated from the residuals (not statistically different from zero) and on precision and accuracy values on the analysis of QC samples, quadratic calibration curves gave the best fit for the concentration/detector response relationship for both EAPB0203 and EAPB0202. R.S.D. values on the slope, b, were $<23.5 \%$. Mean back-calculated concentrations are presented in Table 1. These results confirmed the robustness and reliability of the developed method.

\subsubsection{Validation}

The analysis of the analyte free samples (six different lots) did not show any interference from endogenous components at the retention times of the three analytes assuring good selectivity.

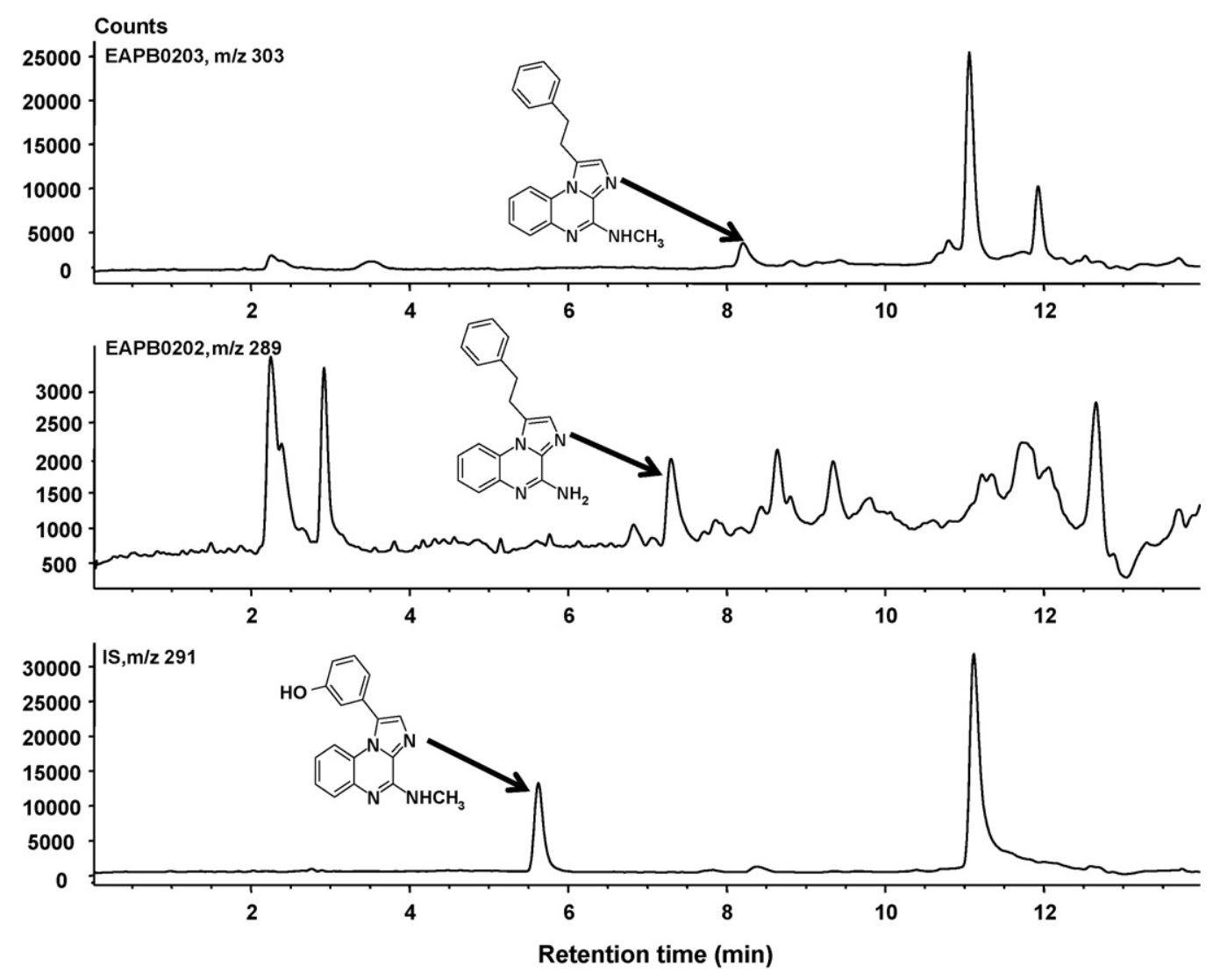

Fig. 1. Typical chromatograms of drug-free rat plasma spiked with EAPB0203 and EAPB0202 at the lower limit of quantitation. 
Table 1

Relative standard deviations and recoveries calculated from back calculated concentrations, from calibration curves performed in rat plasma.

\begin{tabular}{cll}
\hline Nominal concentrations $(\mu \mathrm{g} / \mathrm{L})$ & \multicolumn{2}{l}{ R.S.D., \% (recovery, \%) } \\
\cline { 2 - 3 } & EAPB0203, $n=14$ & EAPB0202 $n=7$ \\
\hline & Low calibration curves & \\
7.5 & $11.8(98)$ & $9.70(102)$ \\
10 & $7.41(102)$ & $9.01(101)$ \\
20 & $4.39(106)$ & $9.04(95.2)$ \\
50 & $4.03(100)$ & $5.35(95)$ \\
100 & $8.34(98)$ & $6.99(104)$ \\
300 & $6.47(98)$ & $5.50(97)$ \\
& $0.97(100)$ & $0.27(100)$ \\
100 & High calibration curves & \\
150 & $4.40(93)$ & $7.80(99)$ \\
400 & $4.68(102)$ & $4.20(104)$ \\
600 & $3.77(104)$ & $7.43(98)$ \\
800 & $2.98(96)$ & $7.57(106)$ \\
1000 & $6.78(100)$ & $4.08(99)$ \\
\hline
\end{tabular}

$n$, number of replicates, R.S.D., relative standard deviation.

The matrix effect was measured by referring the post-extracted spiked samples to the unextracted samples. The results indicated that no significant matrix effects were occurring; the mean matrix factors ranged from $92.5 \%$ to $113 \%$ (R.S.D.s, $1.0-5.0 \%$ ). Extraction yields data calculated at concentrations of QC samples were $75 \%$ for EAPB0203 (CV, 7.7\%), 77\% for EAPB0202 (CV, 12.7\%) and 72.4\% for the internal standard (CV, 10.9\%), confirming the good efficiency of the extraction procedure. The overall interday precision and accuracy data are presented in Table 2. They were satisfactory, with mean accuracy values ranging from $92 \%$ to $108 \%$ and the R.S.D.s were lower than $11.5 \%$. Dilution has no influence on the performance of the method. After a 5-fold dilution, precision on the results were $<8 \%$. The corresponding accuracy values were $100 \%$ for EAPB0203 and 90\% for EAPB0202. The LLOQ was $5 \mu \mathrm{g} / \mathrm{L}$.

\subsubsection{Stability essays}

The stability of the stock solutions was at least 1 month at $4{ }^{\circ} \mathrm{C}$. Spiked plasma QC samples with EAPB0203 and EAPB0202, stored at $-80^{\circ} \mathrm{C}$, were analyzed and stability was demonstrated for 1 month. After bench-top storage at room temperature and at $4{ }^{\circ} \mathrm{C}$ for $4 \mathrm{~h}$, recoveries were $>91 \%$. Repeated freeze/thaw cycles did not affect the stability of EAPB0203 and EAPB0202. Reconstituted extracts in the acetonitrile-water-formic acid mixture were stable in the autosampler for $48 \mathrm{~h}$ at $4{ }^{\circ} \mathrm{C}$.

\subsection{In vitro cytotoxic activity}

EAPB0203 produced significant in vitro growth inhibition against both A375 and M4Be cell lines. This compound was much more active than fotemustine and imiquimod used as references.

Table 2

Between-day accuracy and precision of the method.

\begin{tabular}{llc}
\hline \multirow{2}{*}{ Nominal concentrations $(\mu \mathrm{g} / \mathrm{L})$} & \multicolumn{2}{l}{ Precision, \% (accuracy, \%) } \\
\cline { 2 - 3 } & EAPB0203, $n=14$ & EAPB0202, $n=7$ \\
\hline Low calibration curves & $6.13(101)$ & $8.89(102)$ \\
15 & $7.54(95)$ & $6.63(101)$ \\
75 & $10.6(101)$ & $9.10(96)$ \\
200 & & \\
High calibration curves & $4.70(108)$ & $10.0(100)$ \\
300 & $3.58(103)$ & $4.72(93)$ \\
500 & $5.30(97)$ & $11.1(92)$ \\
750 & &
\end{tabular}

Table 3

$\mathrm{IC}_{50}$ values against $\mathrm{A} 375$ and M4Be human melanoma cancer cell lines.

\begin{tabular}{lllc}
\hline Compounds & Formula & \multicolumn{2}{l}{$\mathrm{IC}_{50}(\mu \mathrm{M} \pm \mathrm{SD})$} \\
\cline { 3 - 4 } & & $\mathrm{A} 375$ & $\mathrm{M} 4 \mathrm{Be}$ \\
\hline EAPB0203 & $\mathrm{C}_{19} \mathrm{H}_{18} \mathrm{~N}_{4}$ & $1.57 \pm 0.56$ & $2.58 \pm 0.40$ \\
EAPB0202 & $\mathrm{C}_{18} \mathrm{H}_{16} \mathrm{~N}_{4}$ & $2.35 \pm 0.15$ & - \\
Imiquimod & & $70.3 \pm 4.3$ & $33.5 \pm 7.7$ \\
Fotemustine & & $173 \pm 24$ & $326 \pm 34$ \\
\hline
\end{tabular}

$\mathrm{IC}_{50}$, concentration of the compound producing 50\% cell growth inhibition after $96 \mathrm{~h}$ of drug exposure, as determined by the MTT assay; SD, standard deviation. Each experiment was run 3 times in triplicate.

Results are presented in Table 3. Concerning EAPB0202, this compound was 1.5 times less active than the parent drug on A375 cell line. Fig. 2 presents the growth-inhibitory effects of EABP0203 and EAPB0202, against A375 human melanoma cell line determined by MTT assay. These curves show a very steep decrease in cell proliferation.

\subsection{In vivo studies}

\subsubsection{Pharmacokinetic profiles}

Semilogarithmic plots of the mean $( \pm S D)$ EAPB0203 and EAPB0202 (active metabolite) plasma concentration-time profiles are presented in Fig. 3. After intravenous administration, pharmacokinetic parameters were as follows: (i) EAPB0203: $\mathrm{CL}, 3.2 \mathrm{~L} / \mathrm{h} / \mathrm{kg}$; $\mathrm{Vd}, 11.1 \mathrm{~L} / \mathrm{kg}$; AUC, $0.78 \mathrm{mgxh} / \mathrm{L}$; and terminal half-life, $2.4 \mathrm{~h}$; (ii) EAPB0202: AUC, $0.029 \mathrm{mgxh} / \mathrm{L}$; and terminal half-life, $2.0 \mathrm{~h}$. After intraperitoneal administration, rapid absorption occurred, pharmacokinetic parameters were: (i) EAPB0203: AUC, $0.15 \mathrm{mgxh} / \mathrm{L}$; and terminal half-life, $1.5 \mathrm{~h}$; (ii) EAPB0202: AUC, $0.032 \mathrm{mgxh} / \mathrm{L}$; and terminal half-life, $0.91 \mathrm{~h}$. The absolute bioavailability of EAPB0203 by intraperitoneal route was $22.7 \%$.

\subsubsection{Sub-acute toxicity}

After repeated administrations, the treatment was well tolerated without weight loss or decrease in food and tap water consumed. The body weight increase and the food and water intake were similar to those recorded in the control group. There were no treatment-associated deaths. No noticeable alterations were recorded in the hematological analyses. The microscopic examination of the organ samples taken did not reveal any alterations related to the administration of the compound.

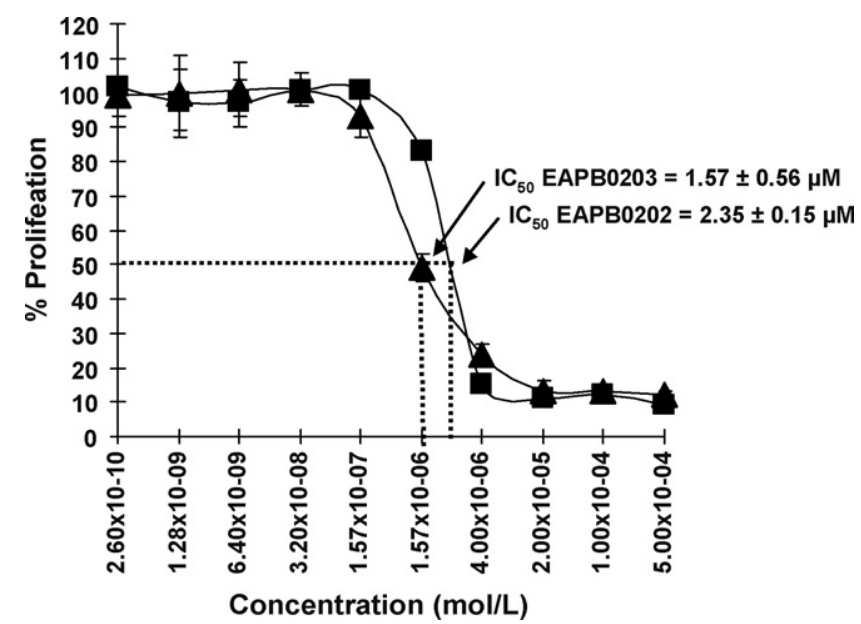

Fig. 2. Effect of EABP0203 ( $\mathbf{\Lambda})$ and EAPB0202 ( $\mathbf{\square})$ on the proliferation of A375 human melanoma cell line using MTT viability assay. Data are the mean of 3 independent experiments carried out in triplicate. Error bars represent SD. 


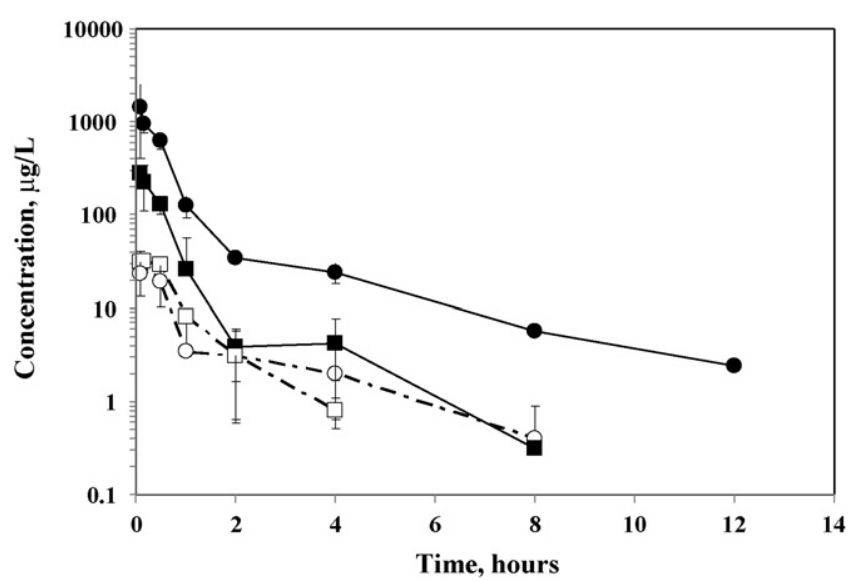

Fig. 3. Plasma concentration time curves after single $2.5 \mathrm{mg} / \mathrm{kg}$ intravenous (๑ EAPB0203; $\bigcirc$, EAPB0202) and intraperitoneal (ロ, EAPB0203; $\square$, EAPB0202) doses of EAPB0203 to male rats (mean \pm SD; three rats per time point).

\subsubsection{In vivo cytotoxic activity}

The treatments were well tolerated without apparent side effects or weight losses. As expected, M4Be xenografts grew progressively in the vehicle control mice. At the dose of $5 \mathrm{mg} / \mathrm{kg}$, the variations in tumor growth, according to the treatment group, have similar profiles than after the $20 \mathrm{mg} / \mathrm{kg}$ dose (Moarbess et al., 2008a). Mice treated with EAPB0203 or fotemustine approached a significant delay in tumor growth. However, lower significant differences between the two groups of treatment were observed than after administration of $20 \mathrm{mg} / \mathrm{kg}$. A significant difference only occurred by day 34 .

The efficacy of treatment is dose-related (Fig. 4A). In mice receiving EAPB0203, the decrease in tumor growth was significantly higher, from day $18(P=0.026)$ to day $46(P \leq 0.005)$ after the $20 \mathrm{mg} / \mathrm{kg}$ dose than after administration of $5 \mathrm{mg} / \mathrm{kg}$. In animals
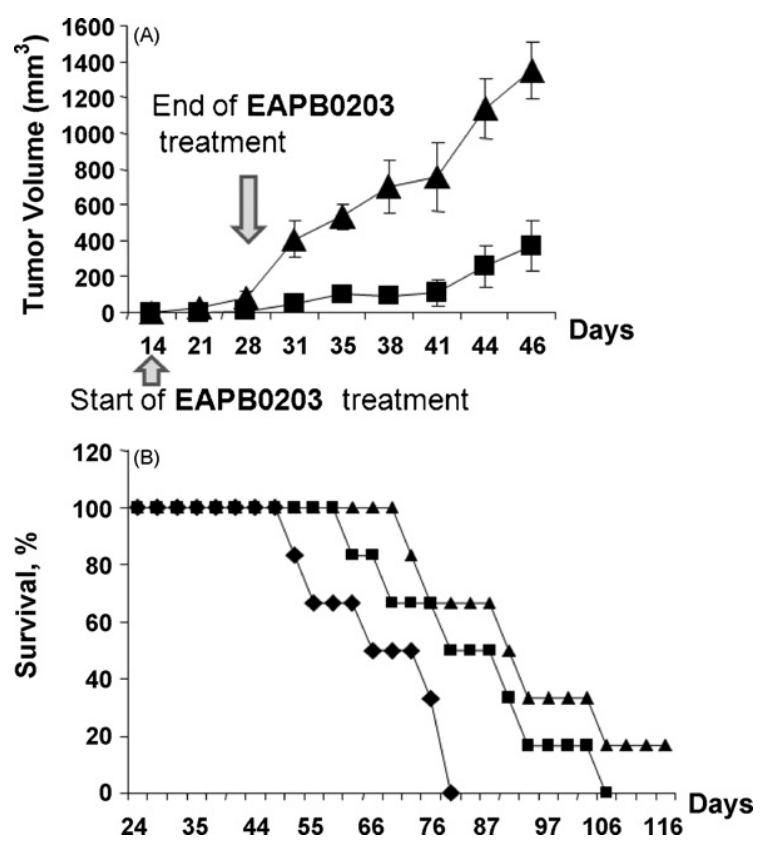

Fig. 4. (A) Antitumoral effect curves of EAPB0203 at two dose levels $5 \mathrm{mg} / \mathrm{kg}$ ( $\mathbf{\Lambda}$ ) and $20 \mathrm{mg} / \mathrm{kg}(\mathbf{\square})$ in human melanoma (M4Be) xenografted nude mice. Data are the mean of one experiment carried out on six mice per group. Error bars represent SD. (B) Survival time in human melanoma (M4Be) xenografted nude mice ( $n=6$ per group): fotemustine ( $20 \mathrm{mg} / \mathrm{kg}$ once a week for 3 weeks) (Ш); EAPB0203 $(20 \mathrm{mg} / \mathrm{kg}$ twice a week for 3 weeks) ( $\mathbf{\Delta})$; $\operatorname{control}(\bullet)$. treated by fotemustine, the difference between the two doses was less pronounced (days $24(P=0.017), 27(P=0.019), 31(P=0.0046)$ and $34(P=0.0052))$.

\section{Discussion}

Since several years, we develop imidazoquinoxaline drugs with interesting anti-tumoral activity against both lymphomas (Moarbess et al., 2008b) and melanoma (Deleuze-Masquéfa et al., 2009a; Moarbess et al., 2008a). We have recently shown that imidazo[1,2-a]quinoxaline derivatives inhibit cyclic nucleotide phosphodiesterase enzymes 4, resulting in increased intracellular cAMP level, and consequently CREB phosphorylation (DeleuzeMasquéfa et al., 2004), and that these compounds activate the p38 MAPK pathway, and inhibit the PI3K pathway (Morjaria et al., 2006). The mechanism of action of ЕAPB0203 has been studied on T cell lymphomas and HTLV-I associated adult Tcell leukemia/lymphoma (Moarbess et al., 2008b). This compound exhibits inhibition of cell proliferation, G2/M cell cycle arrest, and induction of apoptosis in HTLV-I transformed and HTLV-I negative malignant T cells while normal resting or activated Tymphocytes are resistant. Furthermore, EAPB0203 almost completely inhibited the growth of freshly isolated ATL cells at concentrations of 1-10 $\mu \mathrm{M}$. EAPB0203 treatment significantly down-regulated the anti-apoptotic proteins C-IAP-1 and Bcl-XL, and resulted in a significant loss of mitochondrial membrane potential, cytoplasmic release of cytochrome $c$, and caspase dependent apoptosis. In addition, in HTLV-I transformed cells only, EAPB0203 treatment stabilized p21 and p53 proteins but had no effect on NF- $\kappa$ B activation. However, the specific cellular target of EAPB0203 remains to be identified.

The method developed herein to quantify EAPB0203 and EAPB0202 in rat plasma has been fully validated in terms of selectivity, accuracy, precision, stability and sensitivity. The lower limit of quantitation was estimated as $5 \mu \mathrm{g} / \mathrm{L}$ for both compounds. We performed two different calibration curves to cover the possible wider range of concentrations to minimise the number of unknown samples to dilute. The sample preparation involved protein precipitation followed by solid-phase extraction, the most efficient procedure to minimize matrix effects (Marchi et al., 2007; Xu et al., 2005). This method was found suitable for the analysis of blood samples drawn during a pharmacokinetic study carried out in rat.

After intravenous administration, systemic clearance of EAPB0203 $(3.2 \mathrm{~L} / \mathrm{h} / \mathrm{kg})$ was notably less than the typical cardiac plasma output in rat, but higher than the average liver and kidney plasma flows (Davies and Morris, 1993). The volume of distribution $(11.1 \mathrm{~L} / \mathrm{kg})$ was well in excess of the total body water volume, suggesting extensive tissue distribution. Biotransformation of EAPB0203 involves demethylation leading to an active metabolite, EAPB0202. For this metabolite, a lower terminal half-life was found after intraperitoneal administration than after intravenous administrations $(0.91 \mathrm{~h}$ versus $2.0 \mathrm{~h})$. After intraperitoneal administration, the limit of the assay sensitivity being reached at $4.0 \mathrm{~h}$ after dosing instead of $8 \mathrm{~h}$ after intravenous administration (Fig. 3), this resulted in an underestimation of the half-life of the terminal part of the curve.

After intraperitoneal administration the absolute bioavailability was $22.7 \%$.

On A375 melanoma cancer cell line, EAPB0203 $\left(\mathrm{IC}_{50}=1.57 \mu \mathrm{M}\right)$ had an in vitro activity 110 times higher than fotemustine $\left(\mathrm{IC}_{50}=173 \mu \mathrm{M}\right)$ and 45 times higher than imiquimod $\left(\mathrm{IC}_{50}=70 \mu \mathrm{M}\right)$. Its metabolite, EAPB0202, had about $65 \%$ of the activity of the parent drug. On M4Be melanoma cancer cell line, EAPB0203 was also more potent than fotemustine and imiquimod. EAPB0203 also presents interesting in vitro anti-tumoral activi- 
ties on other cancer cell lines (Moarbess et al., 2008a). In mouse xenograft model, EAPB0203 is more potent than fotemustine both after administration of 5 and $20 \mathrm{mg} / \mathrm{kg}$ intraperitoneally (Moarbess et al., 2008a). At the dose of $20 \mathrm{mg} / \mathrm{kg}$, the effect of EAPB0203 on mice survival time is presented in Fig. 4B. The survival time was increased up to approximately 4 weeks compared to control mice and up to 2 weeks compared to mice treated by fotemustine. The results of this study demonstrate the relationship between the dose of EAPB0203 and its effects on tumor growth (Fig. 4A). Taking into account the bioavailability of EAPB0203 after intraperitoneal administration in rat of $22.7 \%$, this compound had remarkable in vivo activity at doses equivalent to 1 and $4 \mathrm{mg} / \mathrm{kg}$ (i.e., $0.227 \times$ dose) entering the systemic circulation.

\section{Conclusion}

EAPB0203 is a promising candidate in the treatment of melanoma and $\mathrm{T}$ lymphomas. This compound exhibits cytotoxicity in tumor models superior to that of fotemustine, both in vitro and in vivo. Due to the double mechanism of action of these compounds: (i) direct by induction of apoptosis (confirmed on $\mathrm{T}$ cell lymphomas, in vitro) and (ii) indirect by production of cytokines, this new series of anticancer agents appears of utmost interest and deserves attention for continuation of preclinical studies. Promising efficacy, tolerance and pharmacokinetic data in mice and rat encourage the development towards patient benefit.

\section{Acknowledgment}

Part of this work was supported by the "Ligue Régionale de Lutte contre le Cancer", Montpellier, France.

\section{References}

Bressolle, F., Bromet-Petit, M., Audran, M., 1996. Validation of liquid chromatographic and gas chromatographic methods. Applications to pharmacokinetics. J. Chromatogr. B: Biomed. Appl. 686, 3-10.

Davies, B., Morris, T., 1993. Physiological parameters in laboratory animals and humans. Pharm. Res. 10, 1093-1095.

Deleuze-Masquéfa, C., Gerebtzoff, G., Subra, G., Fabreguettes, J.R., Ovens, A., Carraz, M., Strub, M.P., Bompart, J., George, P., Bonnet, P.A., 2004. Design and synthesis of novel imidazo[1,2-a]quinoxalines as PDE4 inhibitors. Bioorg. Med. Chem. 12, 1129-1139.

Deleuze-Masquéfa, C., Moarbess, G., Khier, S., David, N., Gayraud-Paniagua, S. Bressolle, F., Pinguet, F., Bonnet, P.A., 2009a. New imidazo[1,2-a]quinoxaline derivatives. Synthesis and in vitro activity against human melanoma. Eur. J. Med. Chem. 44, 3406-3411.

Deleuze-Masquéfa, C., Moarbess, G., Pinguet, F., Bazarbachi, A., Bonnet, P.A., 2009b. Imidazo[1,2-a]quinoxalines et leurs dérivés pour le traitement des cancers. Patent no. FR 2921927

Deleuze-Masquéfa, C., Moarbess, G., Pinguet, F., Bazarbachi, A., Bressolle, F., Bonnet P.A., 2009c. Imidazo[1,2-a]quinoxalines et leurs dérivés pour le traitement des cancers. Patent no. WO 2009043934

Farenc, C., Fabreguette, J.R., Bressolle, F., 2000. Pk-fit: a pharmacokinetic pharmacodynamic and statistical data analysis software. Comput. Biomed. Res. 33, 315-330.
Greinert, R., 2009. Skin cancer: new markers for better prevention. Pathobiology 76, 64-81.

Hemmi, H., Kaisho, T., Takeuchi, O., Sato, S., Sanjo, H., Hoshino, K., Horiuchi, T., Tomizawa, H., Takeda, K., Akira, S., 2002. Small anti-viral compounds activate immune cells via the TLR7 MyD88-dependent signaling pathway. Nat. Immunol. 3, 196-200.

Hengge, U.R., Cusini, M., 2003. Topical immunomodulators for the treatment of external genital warts, cutaneous warts and molluscum contagiosum. Br. J. Dermatol. 149, 15-19.

Kang, H.Y., Park, T.J., Jin, S.H., 2009. Imiquimod, a toll-like receptor 7 agonist, inhibits melanogenesis and proliferation of human melanocytes. J. Invest. Dermatol. 129, 243-246.

Khier, S., Moarbess, G., Deleuze-Masquéfa, C., Margout, D., Solassol, I., Pinguet, F., Bonnet, P.A., Bressolle, F., 2009. Quantitation of two imidazo[1,2-a]quinoxaline derivatives (EAPB0503 and EAPB0603) with anti-tumoral activity in human and rat plasma by liquid chromatography-electrospray mass spectrometry. Application to a pharmacokinetic study. J. Sep. Sci. 32, 1363-1373.

Marchi, I., Rudaz, S., Selman, M., Veuthey, J.L., 2007. Evaluation of the influence of protein precipitation prior to on-line SPE-LC-API/MS procedures using multivariate data analysis. J. Chromatogr. B: Analyt. Technol. Biomed. Life Sci. 845, 244-252.

Moarbess, G., Deleuze-Masquéfa, C., Bonnard, V., Paniagua, S., Vidal, J.R., Bressolle, F., Pinguet, F., Bonnet, P.A., 2008a. In vitro and in vivo antitumoral activities of imidazo[1,2-a]quinoxaline, imidazo[1,5-a]quinoxaline, and pyrazolo[1,5a]quinoxaline derivatives. Bioorg. Med. Chem. 16, 6601-6610.

Moarbess, G., El-Hajj, H., Kfoury, Y., El-Sabban, M.E., Lepelletier, Y., Hermine, O. Deleuze-Masquéfa, C., Bonnet, P.A., Bazarbachi, A., 2008b. EAPB0203, a member of the imidazoquinoxaline family, inhibits growth and induces caspase dependent apoptosis in T cell lymphomas and HTLV-I associated adult T-cell leukemia/lymphoma. Blood 111, 3770-3777.

Morjaria, S., Deleuze-Masquéfa, C., Lafont, V., Gayraud, S., Bompart, J., Bonnet, P.A., Dornand, J., 2006. Impairment of TNF-alpha production and action by imidazo[1,2-a] quinoxalines, a derivative family which displays potential antiinflammatory properties. Int. J. Immunopathol. Pharmacol. 19, 525-538.

RDPP, 1999. Pk-fit Computer Program, Version 2.1. RDPP, Montpellier, France.

Rudy, S.J., 2002. Imiquimod (Aldara): modifying the immune response. Dermatol. Nurs. 14, 268-270.

Sauder, D.N., 2003. Imiquimod: modes of action. Br. J. Dermatol. 149 (Suppl. 66), $5-8$.

Schön, M.P., Wienrich, B.G., Drewniok, C., Bong, A.B., Eberle, J., Geilen, C.C., Gollnick, H., Schön, M., 2004. Death receptor-independent apoptosis in malignant melanoma induced by the small-molecule immune response modifier imiquimod. J. Invest. Dermatol. 122, 1266-1276.

Schön, M., Bong, A.B., Drewniok, C., Herz, J., Geilen, C.C., Reifenberger, J., Benninghoff, B., Slade, H.B., Gollnick, H., Schön, M.P., 2003. Tumor-selective induction of apoptosis and the small-molecule immune response modifier imiquimod. J. Natl. Cancer Inst. 95, 1138-1149.

Spaner, D.E., Miller, R.L., Mena, J., Grossman, L., Sorrenti, V., Shi, Y., 2005. Regression of lymphomatous skin deposits in a chronic lymphocytic leukemia patient treated with the Toll-like receptor-7/8 agonist, imiquimod. Leuk. Lymphoma 46, 935-939.

Steinmann, A., Funk, J.O., Schuler, G., Von den Driech, P., 2000. Topical imiquimod treatment of a cutaneous melanoma metastasis. J. Am. Acad. Dermatol. 43, 555-556.

van Egmond, S., Hoedemaker, C., Sinclair, R., 2007. Successful treatment of perianal Bowen's disease with imiquimod. Int. J. Dermatol. 46, 318-319.

Viswanathan, C.T., Bansal, S., Booth, B., DeStefano, A.J., Rose, M.J., Sailstad, J., Shah, V.P., Skelly, J.P., Swann, P.G., Weiner, R., 2007. Quantitative bioanalytical methods validation and implementation: best practices for chromatographic and ligand binding assays. Pharm. Res. 24, 1962-1973.

Xu, X., Mei, H., Wang, S., Zhou, Q., Wang, G., Broske, L., Pena, A., Korfmacher, W.A. 2005. A study of common discovery dosing formulation components and their potential for causing time-dependent matrix effects in high-performance liquid chromatography tandem mass spectrometry assays. Rapid Commun. Mass Spectrom. 19, 2643-2650. 